$\begin{array}{ll}\text { Received } & : \text { : } 10 \text { Agustus } 2020 \\ \text { Revised } & : \text { 13 Desember } 2020 \\ \text { Accepted } & : \text { 14 Desember } 2020 \\ \text { Online } & : \text { 15 Desember } 2020 \\ \text { Published } & : \text { 18 Desember 2020 }\end{array}$

\title{
Analysis Management of Ornamental Plant Care on The Asri Taman and Sanggar Indah Jaya Store in Cempaka Putih Sub-District
}

\author{
Imam Safir Alwan Nurza ${ }^{1, a)}$, Muhammad Abdurrahman Ihsan ${ }^{2}$, Adam \\ Awaludin Akbar ${ }^{3}$ \\ ${ }^{I}$ Biology Study Program, Faculty of Science and Mathematics, State University of Jakarta \\ ${ }^{2}$ Mechanical Engineering Education Program, Faculty of Engineering, State University of Jakarta \\ ${ }^{3}$ Elektronical Engineering Education Program, Faculty of Engineering, State University of Jakarta \\ $\bowtie:{ }^{a)}$ imamsafiralwannurza2017@gmail.com
}

\begin{abstract}
Management of ornamental plant care is regulated on how to care for ornamental plants both in the form of herbs and succulents nor woody plants such as shrubs and trees, so that it can produce quality ornamental plants. The research purpose was to find out the management of ornamental plant care on Asri Taman and Sanggar Indah Jaya stores. The plant store population found there are four shops until the samples can be taken are two shops. The sampling technique used to random sampling which takes a random sample from the population. Data collection techniques by interview and observation. Interview with information from sources related to the management of ornamental plant care in the store. Observation by observing ornamental plants both in the form of herbs and succulents nor woody such as shrubs and trees. The research resulted that Asri Taman and Sanggar Indah Jaya stores that are very good in regulating watering, fertilizing, and giving pesticides in ornamental gardens which are indicated by green leaves, not wilting, and not growing adventitious roots on the stem, so that it can produce quality ornamental plants.
\end{abstract}

Keywords: Fertilizing, Giving Pesticides, Management, Ornamental Plants, Watering

\section{INTRODUCTION}

The ornamental plant is plants that are widely planted because they create an impression of beauty and provide appeal to many communities. According to Wiryanta (2007), the ornamental plant, in general, are a mixture of various types of plants. These types of plants can include succulents, herbs, shrubs, and trees. Each type of plant to still have the impression of beauty and attractiveness is needed for plant care. Plant care can be carried out in the form of watering, fertilizing, and giving pesticides so that it still produces good quality plants of beauty and attractiveness to the community. Plant care is carried out very specifically so that for ornamental plants carried out special care, one of which is the care of ornamental plants. Care of ornamental plants in caring for ornamental plants both in the form of watering, fertilizing, and giving pesticides is very different from other plants (Sihotang et al., 2019; Indriani, 2011; Arsyad et al., 2018; Rahayu et al., 2014; Lentola et al., 2017). Therefore, the care of ornamental plants in producing beautiful and attractive plants is needed management.

According to Arsyad et al. (2018), management is an activity, process, and effort that is carried out to achieve certain goals. Therefore, management of ornamental plant care is to regulate how to care for ornamental plants so that they can produce quality and beautiful plants that have an appeal. This quality ornamental plant can attract many people so that it can increase plant sales. 
Based on the results of the research that has been explored, the researcher did not find any research similar to the things researched. However, finding research that is almost similar to was researched. Research by Sitohang et al. (2019) entitled "Plant Management in Nursery Kranggan, Bekasi, West Java". The research resulted that the maintenance of plants carried out regularly includes: watering, fertilizing, seeding, plant consolidation, and weeding. Watering was done to maintain the availability of water in the soil so that the frequency of watering is very often ordered to plants grow well. Watering was done in the morning and afternoon. Weeding was done to remove weeds that grow around the plant and usually in conjunction with fecal planting media (Wiryanta, 2007; Wahyudi and Hatta, 2009; Indriani, 2011; Arsyad et al., 2018).

The loosening of planting media aims to increase soil aeration so that nutrient absorption is more efficient. Some plants are consolidated by mounting support poles, especially vines or plants whose branches are not strong enough to support other parts. The support poles are arranged so that in addition to supporting growth they also provide additional aesthetic value. Fertilization is done to maintain the availability of nutrients needed by plants. The fertilizer was used compost and synthetic fertilizer. Compost in the form of the roasted husk, cow dung, and leaf processing. While synthetic fertilizers in the form of liquid and solid fertilizers such as NPK and urea. Spraying is done using insecticides and liquid fertilizer. The insecticide works to prevent or eradicate insects and plant lice (Budiana, 2007; Wahyudi and Hatta, 2009; Alfandi et al., 2014; Rahayu et al., 2014; Adiputro, 2012; Sihotang et al., 2019; Lentola et al., 2017). Therefore, the research purpose was to find out the management of ornamental plant care at the Asri Taman and Sanggar Indah Jaya stores in Cempaka Putih Sub-District. So that, the information was obtained about how to care for ornamental plants to improve their quality in attracting many customers to the store.

\section{METHOD}

This research uses the descriptive method because it can provide an overview of the management of ornamental plant care through analysis with a scientific approach according to two shops, it was Asri Taman and Sanggar Indah Jaya. The plant store population in this study contained four shops found in Cempaka Putih Sub-District so, the samples that could be taken were two shops. Then, the sampling technique at random sampling takes samples randomly from the population.

Furthermore, data collection from the sample is done using two data collection techniques, which is interview and observation. The interview was conducted to find out information obtained from sources related to the management of ornamental plant care at the store. Then, the observation was carried out by observing ornamental plants found in both stores.

According to Rachmawati (2007), interviews are a form of data collection used in qualitative research. This interview has a purpose in the conversation to get the information needed in the research. Observation is collecting data or information that must be carried out by conducting observation efforts directly to the place to be investigated (Arikunto, 2006).

\section{RESULT AND DISCUSSION}

Based on the result of observation and interview conducted at two ornamental plant shops, which is Sanggar Indah Jaya and Asri Taman. The Sanggar Indah Jaya store caring for ornamental plants by watering twice a day at $7 \mathrm{am}$ and $5 \mathrm{pm}$. Then fertilizing is done together with the regulation of pesticides. Fertilization using manure, NPK (Nitrogen, Phosphate, and Potassium), and urea. NPK functions to form cells and tissues and help vegetative growth (Budiana, 2007; Wahyudi and Hatta, 2009; Alfandi et al., 2014). While urea has a role as the formation of vegetative parts in plants, as well as forming fat and stimulating leaf growth (Wahyudi and Hatta, 2009; Alfandi et al., 2014; Adiputro, 2012; Indriani, 2011).

Provision of pesticides using two ingredients, it was osmocote and liquinox (vitamin B1). Osmocote regulating is done by sprinkling on fertilizer evenly and liquinox (vitamin B1) is mixed with fertilizer to kill pests and stimulate root growth. According to Budiana (2007), osmocote is useful as soil fertilizers and also to reduce the amount of nutrient loss resulting from washing and binding of the soil. Liquinox functions in adaptation processes such as maintaining ion balance and 
increasing biosynthesis (Adiputro, 2012; Sihotang et al., 2019). All treatments are carried out evenly, both from watering and fertilizing and distributing pesticides. In this shop, there are some ornamental plants including cactus (Cereus tetragonus L.), mother-in-law's tongue (Sansevieria L.), camboja flowers (Plumeria L.), pine (Pinus merkusii L.), cycas (Cycas rumphii L.), red shoots (Syzygium paniculatum L.), pomegranate (Punica granatum L.), madras thorn (Pithecelobium dulce L.), korean banyan (Ficus Coreana Thunb.), jasmine flowers (Jasminum sambac L.), night-flowering jasmine (Nyctanthes arbor-tristis L.), and dona carmen (Aglaonema L.).

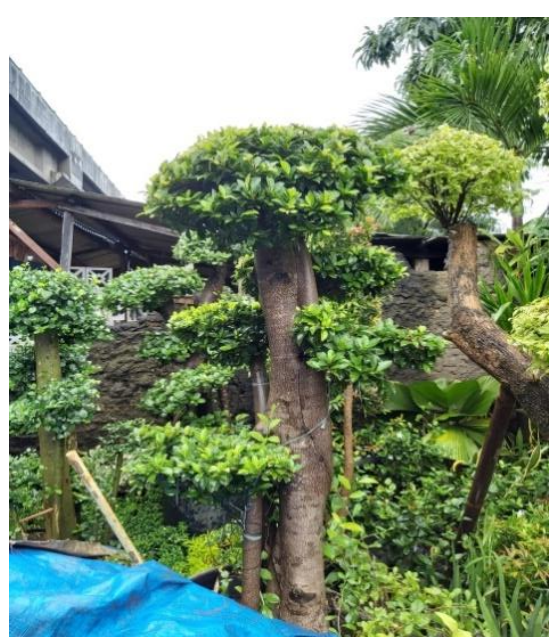

(a)

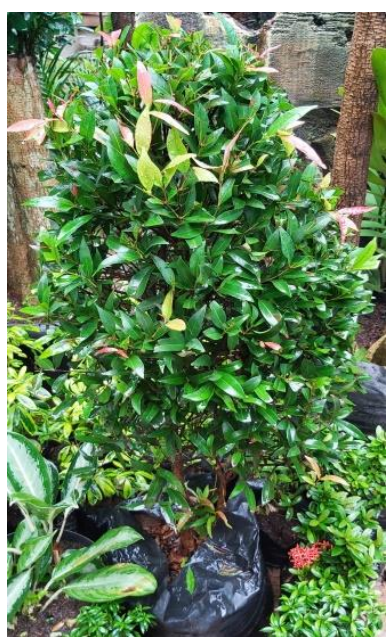

(b)

FIGURE 1. Pomegranate (a) and Red Shoots (b)

The Asri Taman shop caring for ornamental plants is done by watering twice a day at 7 am and 5 pm just like at the Sanggar Indah Jaya store. Then, fertilizing is done twice a week. There are two fertilizers used, compost and goat feces. According to Indriani (2011), compost fertilizer works to improve soil structure, increase the binding capacity of sandy soil and increase the holding capacity of water to the soil, and improve drainage in the soil. Goat feces function is to increase soil porosity.

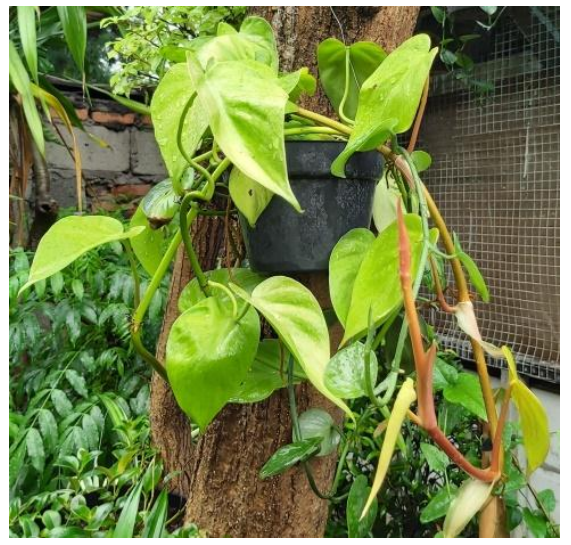

(a)

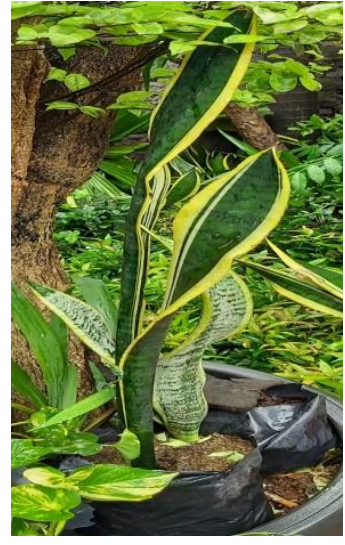

(b)

FIGURE 2. Betel (a) and Mother-in-Law's Tongue (b)

Provision of pesticides using liquinox (vitamin B1) to kill pests and stimulate root growth. Provision of termites by using furadan. According to Alfandi et al. (2014), furadan functions as plant protection so it not to be attacked by pests and disease. Ornamental plants in this shop, including betel (Piper betle L.), pomegranate (Punica granatum L.), madras thorn (Pithecelobium dulce L.), and night-flowering jasmine (Nyctanthes arbor-tristis L.). Ornamental plants in both stores are green leaves and not wilt and show no adventitious roots in the stems. This because the maintenance 
management carried out by the two shops is very good so that no plants are stressed due to lack of water and nutrients and are free from pests.

\section{CONCLUSION}

Based on the results of interviews and observations that have been carried out, it was found that plant maintenance management in two shops, which is Asri Taman and Sanggar Indah Jaya do watering twice a day at $7 \mathrm{am}$ and $5 \mathrm{pm}$ every day. Fertilization using compost, NPK (Nitrogen, Phosphate, Potassium), urea, and goat feces. Provision of pesticides using osmocote, liquinox (vitamin B1), and prototype. Watering, fertilizing, and administering pesticides by these two shops can produce quality plants so that they can provide beauty and attractiveness that can increase sales at both stores.

\section{REFERENCES}

Adiputro, I Gede Ketut. (2012). Pengaruh Auxin dan Nutrient Terhadap Viabilitas dan Pertumbuhan Bibit Anggrek Botol pada Lingkungan Ex-Vitro. Widya Biologi. 3 (2): 1-9.

Alfandi, Wahyuni, Siti, Ipa, Ajran. (2014). Pengaruh Takaran Pupuk Nitrogen dan Pupuk Kalium Terhadap Pertumbuhan dan Hasil Tanaman Tomat (Lycopersicum Esculentum Mill.) Kultivar Permata. Jurnal Agroswagati. 2 (2): 189-198.

Arikunto, Suharsimi. (2006). Prosedur Penelitian Suatu Pendekatan Praktek. Jakarta: Rineka Cipta. Arsyad, et al. (2018). Manajemen Perawatan. Yogyakarta: Deepublish.

Budiana, N.S. (2007). Memupuk Tanaman Hias. Jakarta: Agrihobi.

Indriani, Yovita Hety. (2011). Membuat Kompos Secara Kilat. Jakarta: Penebar Swadaya.

Lentola, A, David, A, Abdul-Sada, A, Tapparo, A, Goulson, D, Hill, E M .(2017). Ornamental Plants on Sale to The Public are a Significant Source of Pesticide Residues with Implications for The Health of Pollinating Insects. Environmental Pollution. 228: 297-304.

Rahayu, Trias, Budi, Simanjuntak, Bistok H., Suprihati. (2014). Pemberian Kotoran Kambing Terhadap Pertumbuhan dan Hasil Wortel (Dacus Carota) dan Bawang Daun (Allium Fistulosum L.) dengan Budidaya Tumpang Sari. Agric. 26 (1): 52-60.

Rachmawati, Imami Nur. (2007). Pengumpulan Data dalam Penelitian Kualitatif: Wawancara. Jurnal Keperawatan Indonesia. 11 (1): 35-40.

Sihotang, Hotmaulina, Silalahi, Marina, Simalago, Erni Murniati. (2019). Manajemen Tanaman di Nurseri Kranggan, Bekasi, Jawa Barat. Jurnal Pro-Life. 6 (1): 89-101.

Wahyudi, Iwan, Hatta, Muhammad. (2009). Pengaruh Pemberian Pupuk Kompos dan Urea Terhadap Pertumbuhan Bibit Pinang (Areca catechu). Jurnal Floratek. 4 (1):1-17.

Wiryanta, B. T. Wahyu. (2007). Media Tanam untuk Tanaman Hias. Jakarta: Agromedia. 